\title{
BUSINESS STRUCTURES AND SUSTAINABLE REGIONAL LEGAL PRACTICE: THE USE OF INCORPORATED LEGAL PRACTICES BY REGIONAL, RURAL AND REMOTE LEGAL PRACTITIONERS
}

\author{
Caroline Hart ${ }^{1}$ \\ Lecturer (Law), PhD student \\ University of Southern Queensland
}

Since 2007 the Legal Profession Act 2007 (Qld) has offered legal practitioners a wider choice of business structures including sole practitioner, partnership, incorporated legal practice and multidisciplinary partnership. In particular, the use of ILPs offers legal practitioners a range of benefits in terms of operating a law firm consistent with business management practices. The status of ILPs, however, comes at the cost of putting in place 'appropriate management systems'. This paper discusses the legislation and literature on the range of business structures then provides an insight into decisions by Queensland regional, rural and remote legal practitioners about what business structures to use. It discusses what is the awareness of the new business structures and are there factors inhibiting regional, rural and remote legal practitioners from their use? The paper draws from over 30 interviews with sole practitioners, partners and directors about their choice of business structure.

\section{Introduction}

The practice of law has changed significantly since the $1970 \mathrm{~s},{ }^{2}$ not only for metropolitan lawyers but also for regional, rural and remote (RRR) lawyers. ${ }^{3}$ This change is due to a number of reasons including: the globalisation of economies; ${ }^{4}$ increased access to information technology; ${ }^{5}$ changing demands and demographics of the work force; ${ }^{6}$ the changing role of lawyers from being advisors to being providers of information; ${ }^{7}$ and the changing demands of clients from being passive to being more actively engaged, in part due to their increased access to legal information through information technology. ${ }^{8}$ Legal services are considered 'big business' in which significant revenue can be generated. ${ }^{9}$ The Australian Bureau of Statistics reports legal services as having an annual revenue of $\$ 6$ billion with an average profit margin of about 30 per cent. ${ }^{10}$

\footnotetext{
1 I would like to acknowledge the contributions of a number of people who have assisted with this article. Firstly, the generosity of those legal practitioners who so willingly gave of their time and experience during our interviews; also the guidance and support of Professor Reid Mortensen and Associate Professor Retha Wiesner in carrying out this research; and the research assistance of USQ Law Librarian, Ms Susanne Schultz.

2 Richard Susskind, The Future of Law: Facing the Challenges of Information Technology (1996); Richard Susskind, The End of Lawyers: Rethinking the Nature of Legal Services (Oxford University Press, 2008); Thomas D Morgan, The Vanishing American Lawyer (Oxford University Press, 2010); Stephen Mayson, Law Firm Strategy: Competitive Advantage and Valuation (Oxford University Press, 2007); and Laura Empson (ed), Managing the Modern Law Firm: New Challenges, New Perspectives (Oxford University Press, 2007).

3 Law Council of Australia and the Law Institute of Victoria, 'Report into the Rural, Regional and Remote Areas Lawyers Survey’ (July 2009) 5.

4 David Wilkins, Globalisation, Technology and the Legal Profession <http://lawprofessors.typepad.com/ mass_tort_litigation/2010/08/david-wilkins-on-globalization-technology-and-the-legal-profession.html>

5 Susskind (1996), above n 2; and Susskind (2008), above n 2.

6 Empson, above n 2.

7 Susskind (1996), above n 2; Susskind (2008), above n 2; and Morgan, above n 2.

8 Susskind (2008), ibid.

9 David H Maister, Managing the Professional Service Firm (The Free Press, 1993); and Mayson, above n 2.

${ }^{10}$ Australian Bureau of Statistics, Legal Practices Australia 2001-02 (2003), cited in Stephen Corones, Nigel Stobbs and Mark Thomas, Professional Responsibility and Legal Ethics in Queensland (Law Book Co, 2008) 96.
} 
Despite the statistics, the practice of law is not experienced uniformly by all legal practitioners. ${ }^{11}$ In particular, RRR legal practitioners are subject to issues unique to their practice because of their geographical location $^{12}$ including the critical issue of a shortage of qualified legal staff. ${ }^{13}$

The Legal Profession Act 2007 (Qld) ('Legal Profession Act') responds to the need for legal practitioners to be able to utilise different 'business models' for legal practice in addition to the traditional sole practice and partnership. These alternate business structures are incorporated legal practice (ILPS) and multidisciplinary practices. This paper deals particularly with the use of an ILP business structures in the RRR context, drawing on feedback from legal practitioners in terms of 'who', 'how' and 'why' they have made use of ILPs.

The findings from this research are important given the increased up-take of the ILP structure. For example, in 2008 the use of ILPs by law firms in Queensland was 3 per cent ${ }^{14}$ but by April 2012 it was 27 per cent. ${ }^{15}$

The exploratory analysis discussed in this paper of the use of ILPs is especially useful when considering the sustainability of RRR Queensland legal practice and builds on early research conducted in New South Wales. This indicates that ILPs are being used for a number of highly pragmatic reasons including succession planning and the smoother entry and exit of partners. ${ }^{16}$ Both of these reasons may be useful to RRR legal practitioners in addressing the shortage of qualified legal practitioners.

\section{Methodology}

This paper is based on doctoral research into the question, 'how and why are RRR Queensland legal practices sustainable? ${ }^{17}$ The hypothesis underpinning the research is that legal practitioners can improve sustainability through the use of certain business management practices including business planning, use of information technology, marketing and people management practices.

Data for the research was gathered in 30 two-hour semi-structured interviews ${ }^{18}$ with principals and legal practitioner directors ${ }^{19}$ of RRR legal practices in Queensland. This paper draws particularly from the responses of participants who have either implemented ILPs or commented upon 'incorporation'. One of the benefits of carrying out in-depth interviews (rather than a mere survey) was that, when commenting on choice of business structure, interview participants also provided rich data concerning associated questions

\footnotetext{
${ }^{11}$ Caroline Hart, 'Sustainable Regional Legal Practice: The Importance of Alliances and the Use of Innovative Information Technology by Legal Practices in Regional, Rural and Remote Queensland' (2001) 16(1) Deakin Law Review 225.

${ }^{12}$ Glenn Ferguson, 'Bush Lawyers: The Problem Facing Regional and Rural Queensland' (2004) 24(11) Proctor 8; Law Council of Australia and the Law Institute of Victoria, above n 3; Recruitment and Retention Working Group, 'Recruitment and Retention of Legal Practitioners to Rural, Regional and Remote Areas Strategy' (Discussion Paper, Law Council of Australia, September 2009) 5; Jennifer Waterhouse and Neal Ryan, 'Retention of Professional Services in Regional Queensland' (Preliminary Research Component - Report to the Regional Communities Engagements, Queensland University of Technology, Department of the Premier and Cabinet, 2004); John Anderson, 'Re-embracing the Bush' (2000) 12(1) Sydney Papers 48; Rachel Castles, 'Recruitment and Retention of Young Lawyers in Remote, Rural and Regional Queensland' (2003) 23(3) Proctor 32; Simon Creek, 'An Articles Year in the South-West' (1999) 26(4) Brief 11; QLS President, 'Bush Lawyers: The Problem Facing Regional and Rural Queensland' (2004) Proctor 8; Josephine Pepe, 'An Articles Year in Northam' (1999) 26(4) Brief 9; Anita Rose-Innes, 'Rural Legal Services Under Spotlight' (2001) 75(1) Law Institute Journal 50; Teresa Russell, 'Across the Great Divide' (2008) 386 Lawyers Weekly 26; Natalie Siegel, 'Bush Courts of Remote Australia' (2002) 76(10) Australian Law Journal 640; Kim Economides and Mark Blacksell, 'The Spatial Analysis of Legal Systems: Towards a Geography of Law?' (1986) 13(2) Journal of Law and Society 161-181; Alex Franklin and Robert G Lee, 'The Embedded Nature of Rural Legal Services: Sustaining Service Provision in Wales' (2007) 34(2) Journal of Law and Society 218; and Donald D Landon, 'Clients, Colleagues, and Community: The Shaping of Zealous Advocacy in Country Law Practice' (1985) 4 American Bar Foundation Research Journal 81.

${ }^{13}$ Law Council of Australia and the Law Institute of Victoria, above $\mathrm{n} 3$.

${ }^{14}$ Legal Services Commission Statistics 2008.

${ }^{15}$ Legal Services Commission, Monthly Performance Report - April 2012, Version 7.0, 14.

${ }^{16}$ Research carried out by Drs Gillian McAllister and John Gray, University of Western Sydney and reported on by Anne Susskind, 'Incorporation is Here, Now, Says Carter New CEO' [2008] (June) Law Society Journal 18.

${ }^{17}$ For a more detailed analysis on how the terms 'regional', 'rural' and 'remote', and 'sustainability' were defined, refer to Hart, above n 11, 231.

${ }^{18}$ The research study has been designed and carried out with reference to the qualitative research literature including: $R$ K Yin, Case Study Research: Design and Methods (Sage, $1^{\text {st }}$ ed, 1989); A Michael Huberman and Matthew B Miles, The Qualitative Researcher's Companion (Sage, 2002); David Silverman, Doing Qualitative Research: A Practical Handbook (Sage, $2^{\text {nd }}$ ed, 2005); and Lyn Richards, Handling Qualitative Data: A Practical Guide (Sage, 2005).

${ }^{19}$ Directors of incorporated legal practices as defined under the Legal Profession Act.
} 
related to approaches to business planning, knowledge sharing ${ }^{20}$ and the allocation of responsibilities within the practice. ${ }^{21}$ This additional data is useful when cross-referenced against the use of ILPs, particularly in relation to the appropriate management systems. ${ }^{22}$

There are limitations to how the data can be used, given the small sample. ${ }^{23}$ However, as the basis of an exploratory research study, the qualitative data provides an opportunity for insight into life as a RRR legal practitioner director that might not otherwise be available. In order to increase validity, the research utilises legal profession and business management literature from Australia, the United States and England, as well as research and experiences of ILPs in New South Wales since the introduction of that state's legislation in 2001.

\section{The establishment of ILPs and the Legal Professions Act 2007 (Qld)}

The Legal Profession Act, ${ }^{24}$, effective from 1 July 2007, was introduced 'to provide for the regulation of legal practice in the interests of the administration of justice and for the protection of consumers of the services of the legal profession and the public generally; and to facilitate the regulation of legal practice on a national basis across State borders'. ${ }^{25}$ One of the benefits of the model laws being developed nationally was the inclusion of new business structure options for legal practices, including incorporated legal practices (ILPs). ${ }^{26}$

The nature of ILPs is provided for under s 111 of the Legal Profession Act. Section 111(1) provides that '[a] corporation is an incorporated legal practice if it engages in legal practice ... whether or not it provides services that are not legal services'. The section also describes instances in which a corporation is not an incorporated legal practice. ${ }^{27}$

The ILP structure provides lawyers with greater flexibility to manage and structure their practices as well as providing tax benefits, enabling the raising of equity capital and avoiding personal and vicarious liability for some breaches made by their partners.

Part 2.7 of the Legal Profession Act provides for the regulation of ILPs. Section 112 provides that an ILP may provide any service and conduct any business that the corporation may lawfully provide or conduct

${ }^{20}$ The interview instruments asked 13 questions on the strategic direction of the law practice including the level and frequency of business planning, who is involved in business planning, and the extent of information and knowledgesharing within the practice.

21 The interview instruments asked: 'To what extent does the law practice divide responsibilities relating to the management, direction and leadership of the practice?'.

22 'Appropriate management systems' identified by the Queensland Law Society include: competent work practices to avoid negligence; effective, timely and courteous communication; timely delivery, review and follow up of legal services to avoid instances of delay; acceptable processes for liens and file transfers; shared understanding and appropriate documentation from commencement through to termination of retainer, covering costs disclosure, billing practices and termination of retainer; timely identification and resolution of the full extent of conflicts of interests; records management, including registers of files, safe custody, financial interests; undertakings to be given with authority including compliance with notices, orders, rulings, directions of other requirements of regulatory authorities such as the LSC, QLS, courts or costs assessors; supervision of the practice and staff; and avoiding failure to account for trust monies. These are taken from Queensland Law Society, QLS Guide to Appropriate Management Systems March 2009 (2008), 2, <https://www.qls.com.au/content/lwp/wcm/connect/resources/file/ebfe674b5616c06/

AMS\%20Guide\%20WEB.pdf?MOD=AJPERES. The Queensland Law Society also includes information on ILPs: Queensland Law Society, Information Kit: Incorporated Legal Practices ('ILPs') Practice Support (Version 7.0 07.07.2010) <www.qls.com.au/.../lwp/wcm/resources/file/ebc41904ec70fc3/QLS_Guides\%20-\%20ILP\%20Information\%20Kit.pdf>.

${ }^{23}$ Based on data from the Queensland Legal Services Commissioner (2008), there are 1363 legal practices in Queensland. From this data and based on the adapted ARIA index, there are 271 'regional, rural and remote' legal practices in Queensland (or 19.9\% of legal practices in Queensland can be termed 'regional, rural and remote'. One-hundred-andsixty of these RRR legal practices were contacted as part of this research study (59\% of the RRR legal practices). Of the 160 RRR legal practices contacted, 30 RRR legal practices responded (or $18.8 \%$ responded).

${ }^{24}$ Under the Legal Profession Act, s 7(4), the following definitions are now worth noting to ensure clarity. A principal of a law practice is an Australian legal practitioner who is: a sole practitioner if the law practice is constituted by the practitioner; a partner in the law practice if the law practice is a law firm; a legal practitioner director in the law practice if the law practice is an incorporated legal practice; or a legal practitioner partner in the law practice if the law practice is a multi-disciplinary partnership. Legal Profession Act Sch 2 notes: a 'sole practitioner means an Australian lawyer who engages in legal practice on his or her own account'; 'Law Firm' means a partnership consisting only of Australian legal practitioners or one or more Australian legal practitioners and one or more Australian-registered foreign lawyers; and Law Practice means an Australian legal practitioner who is a sole practitioner or a law firm or an incorporated legal practice or a multi-disciplinary partnership.

${ }^{25}$ Legal Profession Bill 2007 (Qld) Explanatory Notes, 1.

${ }^{26}$ Ibid, Explanatory Notes, 2. The other new business structure option was multidisciplinary practices.

27 Legal Profession Act, s 111(2) - (3). 
except for a managed investment scheme. ${ }^{28}$ Corporations are eligible to be incorporated legal practices. ${ }^{29}$ This means that 'a law firm can become a private or public company and can take advantage of the benefits of limited liability of directors and shareholders (who may be legal practitioners within the new company), along with a number of other potential financial and organisational benefits (including the sharing of receipts with non-lawyers)'.${ }^{30}$ Before the Legal Profession Act, practitioners who wanted to share the receipts of their practices with unqualified persons had to gain the Queensland Law Society's (QLS) approval under the now repealed rule 78 of the Queensland Law Society Rules 1987 (Qld). ${ }^{31}$

Section 128 of the Legal Profession Act declares that nothing under the Act prevents an Australian legal practitioner from sharing ILP receipts, revenue or other income arising from the provision of legal services by the practitioner.

The Legal Profession Act requires that an ILP must have at least one legal practitioner director. ${ }^{32}$ Section 119 requires an ILP to not be without a legal practitioner director for a period exceeding seven days. ${ }^{33}$ Further, each legal practitioner director is responsible for the management of the legal services provided by the practice. ${ }^{34}$ Each legal practitioner director of an ILP must ensure that appropriate management systems are implemented and maintained. ${ }^{35}$

The Legal Services Commissioner (LSC) or Law Society (as the defined ILP authority under Legal Profession Act sch 2) may conduct an audit of an ILP about compliance by the practice, its officers and employees with the Legal Profession Act, regulations and the legal profession rules, and regarding the management of the provision of legal services by the ILP. ${ }^{36}$

\section{The roles of the Queensland Law Society and the Legal Services Commission}

According to the Commission ${ }^{37}$ the dual role of itself and the QLS is fulfilled as follows: the LSC takes a regulatory responsibility through carrying out 'compliance audits' and 'ILP investigation'; and every corporation that notifies the QLS of its intention to commence legal practice in Queensland must undertake a 'self-assessment' audit of its management systems and report the findings to the LSC for further action as appropriate.

By contrast, the QLS provides a service role to its members by supporting ILPS and law firms that are considering incorporation, helping them to comply with their obligations to have appropriate management systems. The QLS does this by advising and assisting firms before, during and after the self-assessment stage with how best to design and implement the kinds of management systems and arrangements that best suit their particular practice. ${ }^{38}$

The need for self-audit puts new responsibilities on law firms which choose to incorporate. Firms deciding to incorporate must inform the QLS and the LSC and conduct the initial self-assessment. A lack of candour in the process could lead to disciplinary proceedings if the ILP has been misleading in the audit. ${ }^{39}$ Legal practitioner directors may defend themselves against a claim of unsatisfactory professional conduct or professional misconduct if they can establish that they took all reasonable steps to ensure that their employees or fellow directors were not engaged in unsatisfactory professional conduct or professional misconduct. ${ }^{40}$

The Legal Profession Act also requires an ILP to: obtain professional indemnity insurance; ${ }^{41}$ to act in accordance with the laws relating to conflicts of interest; ${ }^{42}$ to provide disclosure relating to legal services and

\footnotetext{
28 Ibid s 112.

29 Ibid s 113.

${ }^{30}$ Corones et al, above n 10, 23.

31 Ibid, 95.

32 Legal Profession Act, s 117(1).

33 Ibid s 119.

34 Ibid s $117(2)$

35 Ibid s $117(3)$

${ }^{36}$ lbid s 130 .

${ }^{37}$ Taken from the Legal Services Factsheet, 'Regulating Incorporated Legal Practices' <www.lsc.qld.gov.au/39.htm>.

38 Ibid.

${ }^{39}$ Corones, above n 10, 107.

${ }^{40}$ Legal Profession Act, s 118 . The Legal Services Commission Discipline Register does not reveal any claims under this provision for 'unsatisfactory professional conduct or professional misconduct'.

41 Ibid s 121.

42 Ibid s 122.
} 
qualifications of the legal service provider; ${ }^{43}$ and to comply with advertising regulations. ${ }^{44}$ Further, the Legal Profession Act extends the vicarious liability of an ILP to the actions of a dishonest officer or employee in relation to the money or property under the direct or indirect control of the practice. ${ }^{45}$

\section{Competing policies surrounding alternative business structures}

Legal practices were subject to limitations on the kind of business structures available to them. As Corones states:

For hundreds of years in the common law jurisdictions, law firms consisted of either sole practitioners or partnerships. Although law firms have always been businesses and have existed primarily to make a profit through the selling of the lawyers' time within a protected market, this has always been done in the context of each individual lawyer owing paramount duties to the court and to the administration of justice. ${ }^{46}$

The limited liability of company directors was considered unsuitable for lawyers whose accountability for their own and their partners professional responsibility was viewed as the best means to prevent fraud and malpractice. ${ }^{47}$ Disallowing incorporation prevented 'law firms from taking on non-lawyers as directors (who do not owe the same ethical duties as lawyers) and from issuing shares in the firm and thereby creating potentially conflicting duties to shareholders whose primary concern is profit (unhampered by a concern for the administration of justice)'. ${ }^{48}$ The concern associated with allowing law firms to access alternative business structures was that it would reduce an individual practitioner's responsibility for the 'competent and ethical provision of legal services and put competing commercial pressures on lawyers' ${ }^{49}$

The relatively recent decision to allow law firms to operate as private and public companies was made from a perceived need to promote competition and to make the management structures of law firms more efficient and transparent. ${ }^{50}$

Mark and Cowdroy, reporting on the pioneering New South Wales legislation in terms of ILPs, identified three reasons why partnerships were viewed as inefficient and not conducive to the creation of a competitive market. Firstly, due to the horizontal management structure of a partnership, decisions are made equally by all partners but with large multi-jurisdiction firms partnership meetings are infrequent and the decision making process is therefore fragmented and cumbersome. Secondly, partnerships cannot raise equity capital to fund expansion and development of new components of the business in the same way that companies can. This prevents partnership firms from funding the growth that is needed to compete at a national and international level. And thirdly, a partnership structure is not subject to the same level of public scrutiny as other business entities, for example, the scrutiny that a company can expect from its creditors, its employees and a range of public agencies.

A counter view to the argument that incorporation might reduce ethical responsibility is that it could actually improve 'the management and culture of each firm as a whole and prevent ethical risks associated with ... the commercial pressures of external investment in legal practice' ${ }^{51}$ This counter view required that ILPS be implemented and maintained using 'appropriate management systems'. ${ }^{52}$ ('Appropriate management systems' are discussed in greater detail later in this paper.)

It seems, then, that ILPs have the capability to both diminish ethical responsibility and improve ethical responsibility. Parker et al sought to test whether the regulation of ILPs through the use of appropriate

\footnotetext{
43 Ibid s 123.

44 Ibid s 126.

45 Ibid s 127.

${ }^{46}$ Corones, above n 10, 101.

47 Ibid.

48 Ibid.

${ }^{49}$ Christine Parker, Tahlia Gordon and Steve Mark, 'Regulating Law Firm Ethics Management: An Empirical Assessment of an Innovation in Regulation of the Legal Profession in New South Wales' (2010) 37(3) Journal of Law and Society, 466, 467 referring to the concerns expressed by B MacEwan, M Regan and L Ribstein, 'Law Firms, Ethics, and Equity Capital' (2008) 21 Georgetown Journal of Legal Ethics 61; and Christine Parker, 'Law Firms Incorporated: How Incorporation Could and Should Make Firms More Ethically Responsible’ (2004) 23 University of Queensland Law Journal 347.

${ }^{50}$ S Mark and G Cowdroy, 'Incorporated Legal Practices - A New Era in the Provision of Legal Services in the State of New South Wales’ (2004) 22(4) Penn State International Law Review 671, 675.

51 Ibid.

52 Ibid. Refer also to John Briton and Scott McLean, 'Incorporated legal practices: Dragging the Regulation of the Legal Profession into the Modern Era’ (2008) 11(2) Legal Ethics 241.
} 
management systems improved their ethical management and behaviour (her findings are discussed further below). ${ }^{53}$ The testing found that, following incorporation under the New South Wales legislation and selfassessment under the appropriate management system, ILP firms were able to combine 'professional ethical values, commercialism (incorporation), and bureaucracy (management)'. ${ }^{54}$

\section{Who is using ILPs in Queensland}

By the end of 2007, 30 of approximately 1300 Queensland Law firms (or 2.3\% of Queensland law firms) ${ }^{55}$ had incorporated, compared with 790 ILPs $^{56}$ (or 18\%) ${ }^{57}$ in New South Wales in 2008 where the relevant statutory provisions allowing for incorporation were enacted in 2001. ${ }^{58}$ By 2012, 27 per cent of all Queensland law firms had become ILPs. ${ }^{59}$

In Queensland, to date, within the RRR context, ILPs have been the choice of sole practitioners rather than the bigger law firms. An analysis of more recent figures (not yet included in this research) may show that the up-take of the ILP structure by the bigger firms has increased. ${ }^{60}$ Parker's findings on New South Wales' ILPs were that they 'are not generally large, sophisticated firms but small firms that probably serve primarily individual and small business clients. ${ }^{61}$

\section{The meaning of 'incorporation'}

Part 2.7, Legal Profession Act relies upon the definitions of 'corporation' and 'director' within the Corporations Act 2001 ('Corporations Act'). To fully understand both the rights and obligations that will co-exist with ILPs, some understanding of what it means to 'incorporate' is necessary. This part of the paper considers the meaning of 'incorporation' in terms of both the Corporations Act and the common law.

The Corporations Act was passed by the Commonwealth Parliament using powers under s 51 (xxxvii) of the Australian Constitution in relation to any matter referred to it by the states. ${ }^{62}$ It became operative on 1 July 2001 following a series of earlier Acts drafted by the Commonwealth and passed by the states.

\section{Features of incorporation}

The Legal Profession Act provides for both private and public companies to be 'incorporated legal practices'. There are a number of features common to both types of company discussed below. Firstly companies are abstract, artificial entities recognised by the law as legal persons with rights and liabilities separate from their shareholders or members. ${ }^{63}$ Under s 119 of the Corporations Act, a company comes into existence as a body corporate at the beginning of the day on which it is registered with the name specified in its certificate of registration. The powers and liabilities of a company are the direct consequence of its creation as a distinct legal entity. ${ }^{64}$ The powers of a company as a body corporate are provided for under $\mathrm{s}$ 124(1) of the Act and include the power to issue shares and debentures, grant options over unissued shares, distribute the company's property among its members, grant a floating charge or give security over uncalled capital, and do anything it is lawfully authorised to do. ${ }^{65}$

A company is a separate legal entity; therefore, it may sue and be sued. A company has limited liability, meaning that shareholders of a company are not personally liable for their company's debts. The extent of a shareholder's liability depends on the type of company as provided by s 112 Corporations Act. ${ }^{66}$

\footnotetext{
${ }^{53}$ Parker et al, above n 49, 468.

54 Ibid 499.

${ }^{55}$ Based on Legal Services Commission Statistics, 2008.

${ }^{56}$ Refer to Parker, above n 49, 481, referring to figures as at 30 June 2008 from Law Society of NSW and OLSC files.

57 Ibid 481 referring to figures as at 2 May 2007 from Law Society of NSW.

${ }^{58}$ Corones, above n 10, 102.

59 Legal Services Commission, above n 15.

${ }^{60}$ Parker et al, above n 49, 481, citing A Boxsell, 'Unsolved Tax Issues Stop Big Firms Incorporating' Australian Financial Review, 24 July 2009, 20, noted that the larger firms were not incorporating on the grounds of negative capital gains tax and stamp duties implications.

${ }^{61}$ Parker et al, ibid.

${ }^{62}$ Phillip Lipton and Abe Herzberg, Understanding Company Law (Law Book Co, 13 ${ }^{\text {th }}$ ed, 2006) 10.

${ }^{63}$ Ibid 24. The leading case on the company as a separate legal entity is Salomon v Salomon \& Co Ltd [1897] AC 22.

64 Ibid.

${ }^{65}$ Ibid 25.

66 Ibid 26.
} 
The company, as a separate legal entity distinct from its shareholders, has been expressed as 'the veil of incorporation'; once a company is incorporated, the courts do not tend to look behind the 'veil' to inquire into the rationale for forming the company or who is controlling it. The dual aspects of the company, being a separate entity together with limited liability, ensures that shareholders are not personally liable to creditors for their company's debts. ${ }^{67}$ Section 516 of the Corporations Act provides that, for a company limited by shares, the shareholder's liability is limited to the amount, if any, unpaid on the nominal value of their shares.

Despite the 'veil of incorporation', both statute law ${ }^{68}$ and common law ${ }^{69}$ can, in some circumstances, make directors personally liable for debts incurred by the company.

\section{Directors' duties}

Directors and legal practitioner directors are subject to a number of duties both under the Corporations Act and the Legal Profession Act. Directors are under both a fiduciary ${ }^{70}$ and a statutory duty to act in good faith and in the best interests of the company. ${ }^{71}$ The duty means that directors must act in the interests of the general body of shareholders, not simply for some shareholders. ${ }^{72}$ Directors are also under a duty to exercise powers for proper purposes. Certain powers are conferred on directors by the board of directors, which generally include broad powers of management including the power to issue shares. The fiduciary duty of directors requires them to exercise their powers for proper purposes. Directors may breach the duty even if they honestly believe their actions are in the best interests of the company as a whole. In considering an 'improper purpose', the courts will look to two matters; firstly the objective purpose for which the power was granted and secondly the purpose which actually motivated the exercise of the power. ${ }^{73}$ However, the courts are generally unwilling to interfere in the internal management of a company unless improper purposes are clearly demonstrated. ${ }^{74}$

The Corporations Act, s 181 provides for the statutory duty to act in good faith in the interests of the corporation and for a proper purpose. Breach of the duty attracts a civil penalty and possibly criminal liability.

Directors are also under a fiduciary duty to retain their discretionary powers. For example, a director will breach this duty if they agree with an outsider to the company to vote in a particular way. ${ }^{75}$

The legal practitioner director then bears considerable responsibility. Very little is written in terms of the impact of this responsibility on directors. Some future insight into this may be useful in terms of ensuring that RRR legal practitioners are appropriately aware of and knowledgeable about the role.

\section{'Appropriate management systems'}

As part of the status of being an incorporated legal practice, legal practitioner directors must ensure that 'appropriate management systems' are put in place. ${ }^{76}$ After incorporation, the systems must be 'kept" ${ }^{77}$ (or maintained) to ensure that the professional and ethical responsibilities of lawyers in an ILP are not com-

${ }^{67}$ Ibid 35.

${ }^{68}$ For statutory lifting of 'the veil' refer to ss 588G, 588J, 588K and 588M, Corporations Act 2001.

69 The common law on lifting 'the veil' is more limited and requires circumstances of fraud, for example Re Darby [1911] 1 KB 95; avoidance of legal obligations for example Gilford Motor Co Ltd v Horne [1933] Ch 935; involvement in directors' breach of duty, for example Green v Bestobell Industries Ltd [1982] WAR 1. For a discussion on 'lifting the veil', refer to Lipton, above $n$ 62, 35 .

70 'A fiduciary duty is an equitable duty to act in good faith for the benefit of another. Persons subject to a fiduciary duty are not permitted to profit from their positions (other than where expressly permitted) or to put themselves in a position where the fiduciary duty and personal interest may conflict: Hospital Products Ltd v United States Surgical Corp (1984) 156 CLR 41'; the definition is taken from Butterworths Concise Australian Legal Dictionary (LexisNexis Butterworths, $3^{\text {rd }}$ ed, 2004) 173.

71 Section 181(1)(a), Corporations Act 2001 requires a director to exercise their powers and discharge their duties in good faith and in the best interests of the corporation.

72 The case law on 'acting in the best interests of the company' is considerable and takes into account that acting in the best interest of the company can include present and future shareholders (Greenhalgh v Arderne Cinemas Ltd [1951] $\mathrm{Ch}$ 286; it also does not mean directors owe a duty to particular shareholders (Percival $\vee$ Wright [1902] 2 Ch 421). For a discussion on the duties, refer to Lipton, above $\mathrm{n} 62$, Ch 13.2 .

${ }^{73}$ Lipton, above n 62, 304.

74 Ibid.

75 Ibid 311.

${ }^{76}$ Legal Profession Act s 117(3).

77 Ibid s 2 provides that the meaning of 'kept' includes 'maintains'. 
promised by the activities of the incorporated body or by the actions of non-practitioner employees of the practice. Each of the legal practitioner directors of an ILP are responsible for ensuring that 'appropriate management systems' are implemented to that end. Section 117(3) provides for the requirements. ${ }^{78}$

\section{Queensland Law Society Guide to 'appropriate management systems'}

The QLS Guide to Appropriate Management Systems ${ }^{79}$ (the QLS Guide) notes that the term 'management systems' is meant to be interpreted broadly and should include all arrangements and procedures that may include some of the following: policies, information technology programs, training programs, meetings and forms. ${ }^{80}$ The QLS Guide acknowledges that in considering what are 'appropriate management systems', 'the size and complexity of the practice, the number, experience and qualifications of staff, and the nature of the work ${ }^{81}$ can all be taken into account.

The Legal Profession Act does not provide a definition of 'appropriate management systems' but, in the interests of consistency with the approach of New South Wales - the State responsible for the development of the system, Queensland has applied a similar approach to that State. ${ }^{82}$ Lawyers who are new to the role of legal practitioner director need to think carefully about the types of systems to put in place to ensure compliance with this seemingly onerous responsibility. ${ }^{83}$

In Queensland, the Legal Profession Act gives both the Legal Services Commission (LSC) and the Queensland Law Society (QLS) powers as the relevant regulatory authorities to audit and test the compliance of ILPs with the 'appropriate management systems' requirement. ${ }^{84}$ The LSC in Queensland provides for ten criteria - listed below - (developed firstly in New South Wales) and the Commission published an initial self-audit for use by ILPs in their internal audit program. ${ }^{85}$

The ten criteria ${ }^{86}$ to be put in place are: competent work practices to avoid negligence; effective, timely and courteous communication; timely delivery, review and follow up of legal services to avoid instances of delay; acceptable processes for liens and file transfers; shared understanding and appropriate documentation from commencement through to termination of retainer, covering costs disclosure, billing practices and termination of retainer; timely identification and resolution of the full extent of conflicts of interests; records management, including registers of files, safe custody, financial interests; undertakings to be given with authority including compliance with notices, orders, rulings, directions of other requirements of regulatory authorities such as the LSC, QLS, courts or costs assessors; supervision of the practice and staff; and avoiding failure to account for trust monies. ${ }^{87}$

The QLS Guide suggests that the ability to incorporate removes some of the barriers that practices face in implementing effective management systems and structures. ${ }^{88}$ In particular, the Guide notes the following barriers: 'a lack of skills, time or enthusiasm for management issues amongst partners; a lack of options and flexibility for motivating, retaining and remunerating specialist non-lawyer managers; a flat partnership decision-making structure which complicates the discussion and implementation of management initiatives; and problems in raising the investment required for effective practice management' ${ }^{89}$

The QLS Guide identifies a number of advantages under the ILP status including that:

\footnotetext{
${ }^{78}$ Corones, above n 10, 105.

${ }^{79}$ QLS Guide to AMS, above $\mathrm{n} 22,9$.

${ }^{80}$ Ibid.

81 Ibid 10

82 Ibid 2.

${ }^{83}$ Corones, above n 10, 106.

${ }^{84}$ The Legal Profession Act SC 2 provides that the ILP authority means the Commissioner or the Law Society or both acting jointly under an arrangement made between them.

${ }^{85}$ Corones, above $\mathrm{n} 10,107$ and the website <www.lsc.qld.gov.au/ILP/regulating-ILPs.html>.

${ }^{86}$ Taken from Corones, above n 10, 106.

${ }^{87}$ QLS Guide to AMS, above n 22, 2. The document provides details on how to implement the 'ten commandments' from pages 15 to 33 .

${ }^{88}$ Ibid 9.

${ }^{89}$ Ibid.
} 
[i]t allows a clearer distinction between ownership, fee-earning and the management activities of the practice. Incorporation status means that, of the lawyers who were partners in the previous partnership, only those who specifically want to, and who the practice agrees should, will either become directors or will retain management duties. This means that management can be left to those with management skills (whether directors, shareholders or employees), while lawyers can focus on providing legal services. This should result in both more effective management, and more effective fee-earning. ${ }^{90}$

\section{New South Wales legal practitioners' experiences of 'appropriate manage- ment systems'}

Reference to research from New South Wales in terms of the impact of 'Appropriate Management Systems' is useful, given that New South Wales has allowed incorporation since 2001. ${ }^{91}$ The New South Wales Office of the Legal Services Commission's Annual Report 2005-2006, which provides results of research into the impact of 'Appropriate Management Systems' in New South Wales is encouraging. The research reveals that 63 per cent of ILPs have significant systems changes as a result of engaging in the self-assessment process. ${ }^{92}$ Parker notes that ' $[\mathrm{t}]$ here has even been some suggestion that it could be useful for the 'Appropriate Management Systems' requirement to eventually apply to all legal practices, not just those that are incorporated'. ${ }^{93}$

The research from the New South Wales experience of implementing 'Appropriate Management Systems' indicated that most were sole practitioners; ${ }^{94} 76$ per cent of ILPs had one principal. ${ }^{95}$ Twenty-six per cent of those implementing 'Appropriate Management Systems' were from a rural location. ${ }^{96}$ In terms of the length of time it took to become compliant with the system, ten per cent recorded compliance within one month and 93 per cent within one year. Fifty-one per cent were compliant within three months. ${ }^{97}$

\section{Conclusions about the 'appropriate management systems'}

The traditional view, that lawyers should not be able to take advantage of the corporate veil to limit their liability because it is inconsistent with the possible harm that might be caused to clients when their lawyers act unethically or unprofessionally, is rather out-dated. In more recent times there is greater emphasis (and professional education) on the implementation of appropriate administrative and management practices by legal practices; these are considered as being a more important (and useful) ways to protect clients. ${ }^{98}$

ILPs are now subject to the same rigorous compliance audits and standards that have long been in place for other businesses as a means of providing effective practice management. The reality seems to be that poor business management and a lack of administrative skills has been the cause of professional breaches, particularly by sole practitioners and smaller legal practices. ${ }^{99}$

\section{Why are ILPs being used? Reflections from Queensland RRR legal practi- tioners on the need for expertise in management skills}

Why might legal practitioners consider an ILP structure? A significant reason may be to provide an increased capacity to enable the implementation of an appropriate management system. The QLS Guide sees the appropriate management system as an opportunity 'to raise the profile and importance of non-lawyer managers as their responsibility increases'. In the past, many law firms have struggled to recruit and retain

\footnotetext{
${ }^{0}$ QLS Guide to AMS, above n 22, 9.

${ }^{91}$ Parker et al, above $\mathrm{n} 49$, report that incorporation has occurred incrementally from 60 ILPs in 2001 to 116 in 2020,118 in 2003 and 179 in 2007. In Queensland, the rate of use of ILPs by legal practices can be seen by comparing 2008 data, revealing 37 legal practices out of 1367 (or 2.7\%) used the ILP structure, with 2012 data, which shows that 421 ILPs out of a possible 1589 legal practices (or $26.5 \%$ ) used the structure.

${ }^{92}$ QLS Guide to AMS, above $\mathrm{n} 22,8$.

${ }^{3}$ Parker et al, above n 49, 22 citing Greg Dwyer, 'The Business of Ethics' (2003) Law Society Journal $38,38$.

${ }^{94}$ Parker et al, lbid 22

${ }^{95}$ Ibid 27. The research was based on information about ILPs from 2008 information supplied by the Law Society of NSW.

96 Ibid 28.

97 Ibid 34

${ }^{98}$ Corones, above n 10, 115

99 Ibid. Refer also to empirical research by Parker et al, above $\mathrm{n} 49$.
} 
managers at the required level because of restrictions on offering equity to non-lawyers. ${ }^{100}$ The Legal Profession Act 'removes this barrier and gives the practice not only the option of offering equity to non-lawyer managers but also more flexibility in motivating and retaining all staff through remuneration'. ${ }^{101}$

An additional advantage of the ILP structure is that it allows for 'more corporate, streamlined decision making structure[s]. With the separation between management and ownership comes greater flexibility to implement arrangements that are designed to efficiently meet the practice's objectives rather than a "flat" decision making structure that is designed to accommodate the views of all dissenting partners. "102

Comments from the Queensland RRR legal practitioners who participated in the doctoral research provided an insight into the complexity of legal practice in terms of the dual roles of running a business and providing legal services. The comments are consistent with the theory that law is both a "business'103 and a profession. One conclusion that can be drawn from the comments is that not all lawyers seek to pursue both roles. The comments below indicate a range of approaches to the roles; from legal practices in which there is a dedicated CEO, managing partner or office manager to carry out the role of running the business side, to legal practices in which one practitioner carries out both roles. In some cases, the comments emphasise the problems legal practitioners experience in effectively managing their legal practices. The comments also provide some insight into 'how' ILPs might assist RRR legal practitioners with providing a structure that rewards expertise in providing effective practice management systems.

The following comment highlights the benefits to partner relations, strategic planning, financial performance and ethical compliance as a result of the creation of the role of 'CEO' for the legal practice:

Two years ago we put in a new structure ... I had been the managing partner for 14 years ... we put in $[X]$ as the CEO. The appointment of the CEO was a major decision. We didn't have a clear road map ... During the last 18 months we've spent time on business drivers and the mechanics to plan and go forward into the next four or five years. We've had to put change in place for the next few years. Operationally we needed to get business to that level of efficiency. We made process and policy changes - to set up for a position about what we do. We understand the business. We are strategic in terms of what we want to achieve. We are concentrating on financial performance - that has been tightened up for example - budgets monthly; that money is in trust; that we are getting good work in. That 'big picture' is needed to have everything humming.

(Partner - previously the Managing Partner)

The following comment clearly identifies the split in responsibilities that are part of a legal practice - the management component and the provisions of legal services component. This comment reveals that both are highly specialised and demanding and involve two very different skill sets. By allocating the roles appropriately, each 'specialist' can more effectively achieve high performance results:

The current partnership ... was formed about eight or nine years ago. The previous law firm I was a partner in was sold - due to restraint of trade. l'd got into management of the law firm - doing a consultancy. It had the current partners in it. That split and each went in as specialists. I got on with the partners - have a great respect for them. I said that I will only be your partner if I have complete and uninterrupted control. They saw what I can do, because I had done the consultancy for $12 / 18$ months. I turned the partnership around from bankruptcy. The elements of it - the partnership makes money. I isolate the partners from the day-to-day rubbish. They want to practice law. (Managing Partner)

The comment below introduces the concept that the management role can be carried out by a non-lawyer. It also highlights both the performance benefits and the impact on the normative environment ${ }^{104}$ of having dedicated management capabilities within the legal practice. In this case the management skills are executed by the office manager:

\footnotetext{
${ }^{100}$ QLS Guide to AMS, above n 22, 9.

101 Ibid.

102 Ibid.

${ }^{103}$ Mayson, above n 2; and Empson, above $\mathrm{n} 2$.

104 The normative environment as a factor contributing towards sustainable RRR legal practice is more fully discussed in Hart, above n 11, 225.
} 
My role is HR. We have an IT manager, marketing partner and a finance partner. My role is the essential day-to-day staff availability - who's sick; who's on leave ... I'm looking at incoming resumes and interviews. I do the paperwork, induction and training, QA changes and I'm the workplace, health and safety officer. The IT manager does IT - who is employed full-time. He's excellent. My role is with dissatisfaction of staff and to be finance wise. We've had Law Master for one year. The accounting was not set up properly and we did not have an accounting person. I was monitoring things, but information was not entered properly. It wasn't processing things properly. This was a time burden on administration staff and it was poorly dealt with by the partners. If something is urgent then staff come to me rather than the partners. I deal with satisfaction so that everyone enjoys coming to work rather than not like the day. There is plenty to do. (Office Manager with ILP)

The earlier remarks emphasise the extent and complexity of non-legal work that is involved in maintaining (and possibly developing) a legal practice. Non-legal work encompasses people management, information technology, accounting, marketing, business planning and regulatory compliance. It is worth noting that from a 'business' perspective, none of this work is billable by the legal practitioner.

By contrast, the following comments reflect the approaches taken by legal practitioners who have carried out both roles (practice management and provision of legal services) either without support or utilising an ad hoc approach.

This first comment reflects the ad hoc approach of allocating the 'management' role of the legal practice, not via an actual decision based on a consideration of the needs of the legal practice, but through indecision or inactivity. The sense revealed from this comment is that the need to provide legal services has been stronger - and dealt with as a priority - than the competing role of providing the practice management role. Rather fortuitously for this legal practitioner, the management capabilities lay within reach of the partners:

The planning has been due to $X$ who has taken on this responsibility. $Y$ [name of partner] is away - the planning is quite poor, but with we have intentions to improve. We [the partners] are not big on planning. We are pleased $X$ and $Y$ have taken on this role. They do the formal planning. I am hopelessly disorganised. I deal with urgent and important matters, or important matters. I don't delegate anything. I am very pedantic and overly thorough. (Partner)

By comparison, the next comment reflects the angst of a sole practitioner who has borne both the management role and the provision of legal services role. There is a deep understanding of the enormity and complexity of the task of operating a legal practice:

I've been trying to hold it together - doing it on my own. The fellow in [rural location] couldn't get organised. He overcharged. We couldn't resolve the disputes satisfactorily; you need an office manager to maintain the office. (Sole Practitioner)

The implication in the above comments is that poor business management may also bring about ethical issues such as over-charging or untimely communication.

The comment below identifies the basis of the dilemma for many legal practitioners: that the priority must be the provision of legal services, at least for the first few years of the life of the practice:

For the first years of the firm I was concentrating on work. If there is work and the money coming in then I don't worry about planning. You tell everyone else but don't do your own. (Sole Practitioner)

The complexity of practice management - including complying with business regulations - is strongly evident in the comment below. The comment is made within the context of a partnership that had not been able to satisfactorily identify and address the practice management role. In the end, the burden of managing the legal practice proved too much:

I was always at meetings. I said that this was no good, and we parted amicably. I decided never to go into partnership again. When this offer with [name of law firm] came up, I merged the practice - the business with [name of Partner]. I wanted to be free of the practice management. I was doing 80 per cent administration - staff and BAS - and 20 per cent law. Law practices are small businesses where the introduction of the GST has impacted on the business. Solicitors took the hit and a 10 per cent reduction in income. That was never factored in. The compliance with red-tape is enormous. The BAS regime is very intrusive and very difficult to implement. The income is in accounts not in cash ... (Partner) 
The comments so far all relate to the issue of how clearly the dual role of 'management' and 'provision of legal services' is identified by members of the legal practice. In the above comments there was a clear understanding of the dual roles and a willingness to provide resources into carrying out the roles (and responsibilities). In the comments noted below, it is apparent that the roles were either not clearly identified or not fully understood (or resourced). The comments are made by sole practitioners - both of whom enjoyed the autonomy of sole practice yet recognised the need to address the management role implicit in legal practice. They indicate a more proactive approach to the need to 'manage' their legal practices:

I'm now fine-tuning - thinking about the cash flow, establishing stable routines, and into 2011. I wanted to bring in training (the conveyancing clerks), but I need to rethink that. It's not working. I value their opinions but ultimately I make the decisions. (Sole Practitioner, Legal Practitioner Director, ILP)

Prior to all this I did courses on the practice management side of this. The business side of the practice - my macro-managing is good - but my micro-managing is not so good. One day a week we have an office manager who does the wages. (Sole Practitioner)

Other commentary on incorporation has been cautious in terms of how incorporation should occur; Mayson notes the benefits of incorporation (over partnership) but suggests that conversion might be best if carried out in stages due to the costs (in terms of time money and effort) and disruption. ${ }^{105}$

\section{Experiences of implementing incorporated legal practices}

The following part of the paper more specifically reports on the experiences of the RRR legal practitioners who were interviewed and who have implemented ILPs. Figure 1 shows the use of ILPs chosen by the participants in the research compared to other business structures (responding to the research question, 'if an ILP is used').

\section{Use of business structures by participant-Qld RRR legal practitioners interviewed}

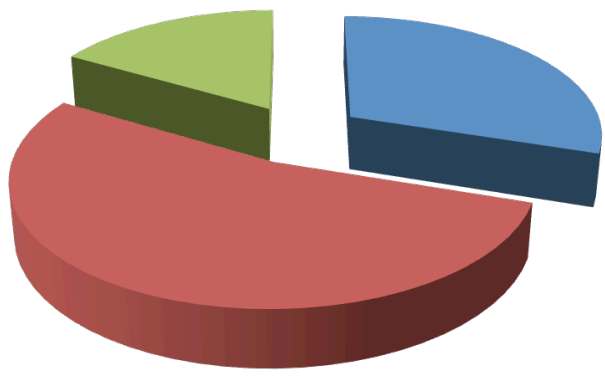

Sole practitioner

Partnership

Incorporated Legal

Practise

Figure 1: Use of business structures by participant-QId RRR interviewed

\section{Location of the RRR legal practitioners}

Legal practitioners were selected from locations that were 'regional', 'rural' and 'remote'. ${ }^{106}$ Ten participants were from a regional location, twelve were located rurally and eight were located remotely. Of the five legal practitioners who used ILPs, four were located rurally and one regionally.

${ }^{105}$ Mayson, above n 2, 322.

${ }^{106}$ Refer to Hart, above n 11, 231 for a discussion of defining 'regional', 'rural' and 'remote', and the diversity of regions. 


\section{Location of the participant-Qld RRR legal practitioners}

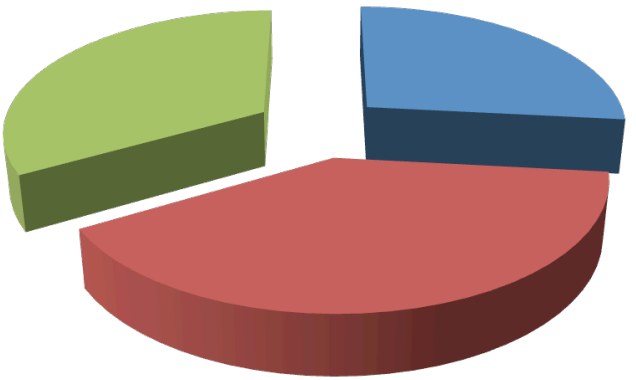

Remote

Rural

Regional

Figure 2: Location of the participant-QId RRR legal practitioners

\section{Qualifications}

The undergraduate qualifications of the thirty participants included 16 who held a Bachelor of Laws, eight held a Bachelor of Laws with another degree and six did not have a university qualification of any kind. With respect to the five participants who had used an ILP, all held Bachelor of Laws, one with honours.

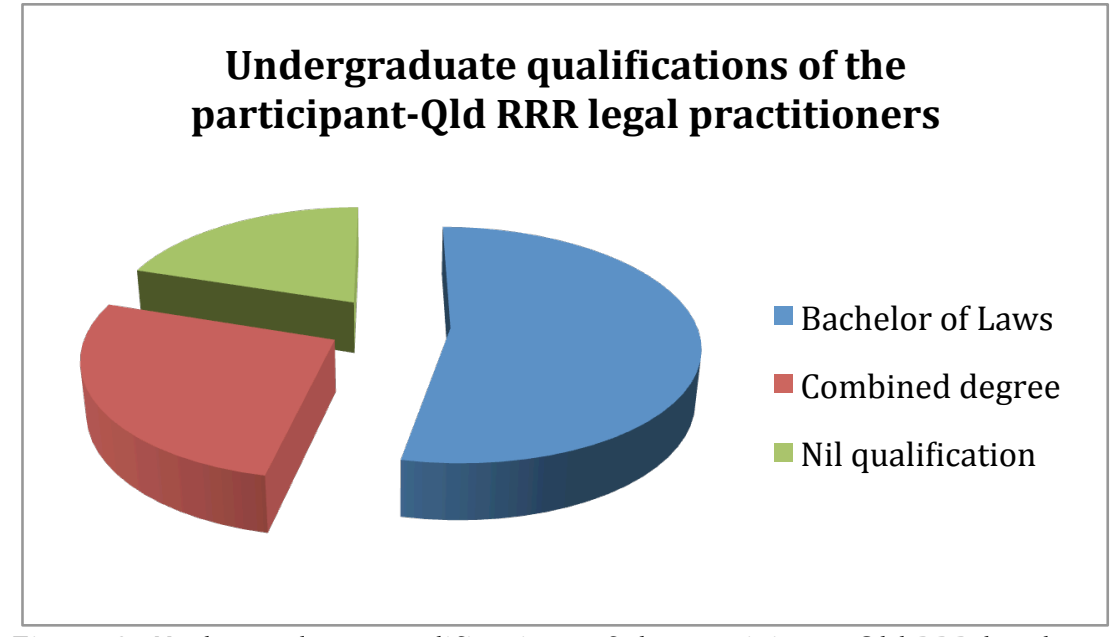

Figure 3: Undergraduate qualifications of the participant-QId RRR legal practitioners

Only five participants held any postgraduate qualifications. Twenty-five did not have any postgraduate qualification.

\section{Method of admission}

The methods of admission to practise as a solicitor have changed over a number of years. The legal profession in Queensland is regulated by the Legal Profession Act 2007, An Act to provide for admission to, and the regulation of, the legal profession. Five participants were admitted through the legal practice course; one through trainee solicitor; 16 were admitted through completion of articles; two through the Bar Board Examinations; two through the Solicitors' Board Examinations; and two through completion of ten years government; two through mutual recognition. 


\section{Methods of admission as a solicitor of the participant-QId RRR legal practitioners}

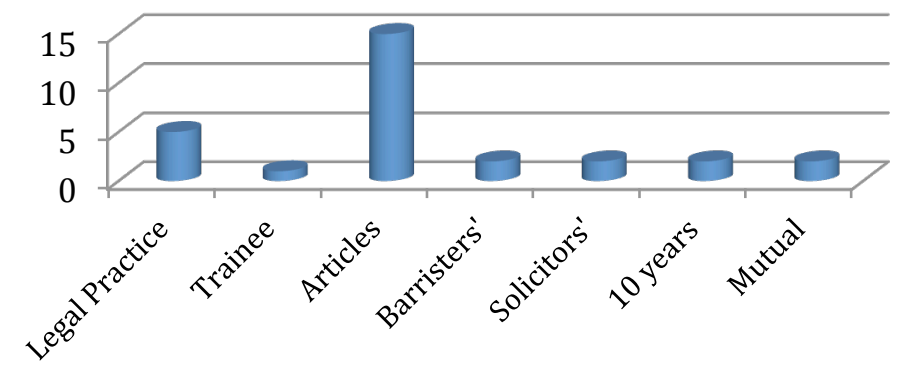

Figure 4: Methods of admission as a solicitor of the participant-QId RRR legal practitioners

Of the five RRR legal practitioners who had used ILPs, three were admitted following completion of a legal practice course; one as a trainee solicitor and one through the Barristers' Board.

\section{Business Planning}

The complexity involved in implementing an ILP warrants an overview of the extent of business planning ${ }^{107}$ used by RRR legal practitioners within the sample group. Of the 30 participants interviewed, 13 rated business planning as a high priority activity in the current year, ten indicated that the frequency was sixmonthly, nine that it was annually and five stated that no business planning occurred.

Of the five RRR legal practitioners who used ILPs only one carried out a formal, annual business planning process, another practitioner had an 'ongoing' approach to business planning, two others carried out business planning to a moderate extent and the fifth RRR legal practitioner did not business planning at all.

With respect to investing in practice management systems the data from ILPs indicated only a low response rate from ILPs established by sole practitioners. By contrast, ILPs established by two or more legal practitioners indicated a higher involvement.

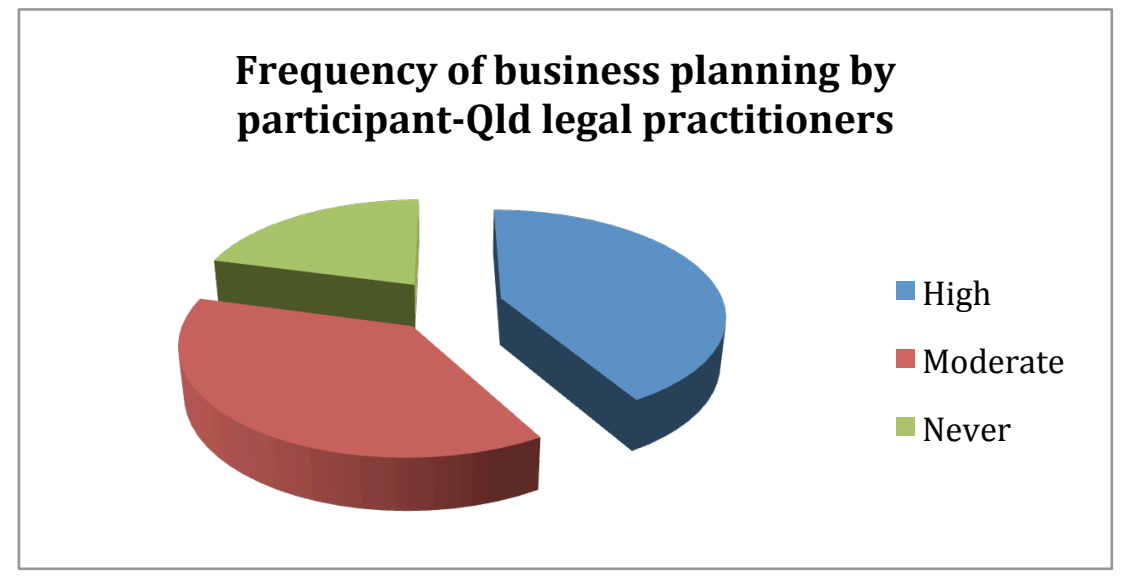

Figure 5: Frequency of business planning by participant-Qld RRR legal practitioners

\footnotetext{
${ }^{107}$ Participants were asked to rate the extent of their formal and informal business planning activities in terms of its occurrence being one of three options: six-monthly, yearly, or no planning. Most participants then went on to respond in more detailed terms how that business planning was carried out in terms of: the levels of formality, who was involved, and to whom the results were provided. See generally the work of Robert S Kaplan and Robin Cooper, Cost \& effect: Using Integrated Cost Systems to Drive Profitability \& Performance (Harvard Business School Press, Boston Massachusetts, 1998); Robert S Kaplan and David P Norton, Alignment: Using the Balanced Scorecard to Create Corporate Synergies (Harvard Business School Press, Boston Massachusetts, 2006); Robert S Kaplan and David Norton, Strategy Maps: Converting Intangible Assets into Tangible Outcomes (Harvard Business School Press, Boston Massachusetts, 2004); and Robert Simons, Performance Measurement \& Control Systems for Implementing Strategy (Prentice Hall, Upper Saddle River, New Jersey, 2000).
} 


\title{
Implementing 'appropriate management systems'
}

The task of implementing an 'appropriate management system' is onerous and time-consuming. The sentiments of the RRR legal practitioner quoted below were echoed by other practitioners:

The establishment of the ILP has involved considerable costs and auditing. The reporting requirements - it all has to be done. (Partner, Legal Practitioner Director, ILP)

This same participant went on to describe the changes that had to be made to the systems of the legal practice in terms of information technology, administration process, communications and document management.

\section{Timing of use of ILP}

The response from the RRR legal profession to take advantage of the new structures has been reasonably quick. As one RRR legal practitioner commented:

I was the first ILP! I faxed the forms through at 6 am on 1 July 2007. (Sole practitioner, Legal

Practitioner Director, ILP)

Other RRR legal practitioners who took part in the research study took up the status of ILP in October 2007, January 2009 and two in August 2009.

\section{Reflections on the benefits from using the new structures}

The benefits of using alternative business structures focussed on perceived financial benefits, improving practice management and opportunities to attract and retain staff.

\section{Financial benefits}

The financial benefits of being able to incorporate were noted by both legal practitioners who had used the ILP structure and by legal practitioners (close to retirement) when they reflected on earlier days when the structure was not available. The following comment clearly articulates the perceived financial benefits that would have been available had incorporation been allowed:

\begin{abstract}
The inability to incorporate ... I was paying top dollar when I was in practice. Accountants, surveyors, doctors - they could all pay 30 per cent. Now we can do that too. The inability to incorporate that made a big difference in my practice. The financial viability situation that I was ignorant of - it has been a source of financial dissatisfaction. The financial situation has been a cause of stress. Some business management knowledge would have eased it ... helped. (Sole practitioner, Legal Practitioner Director ILP)
\end{abstract}

As noted earlier, the use of the ILP structure in RRR has been among sole practitioners (rather than large law firms). The interviews revealed that one of the rationales for the choice of ILP may have included hesitancy against partnership (due to the joint liability) and the desire for financial protection from an errant partner. The following comments indicate the reluctance to enter into a partnership by two RRR legal practitioners who have used the ILP structure:

I would do it [business structure] as a family business - but never as a partnership. I wouldn't consider a partnership. The company structure is better - it's governed by shares. You could issue more shares. (Sole Practitioner, Legal Practitioner Director ILP)

\section{Improved practice management structures}

Despite the costs of using an ILP business structure, some comments from the RRR legal practitioners revealed that there were some significant benefits to be gained. Again, the sample is too small to draw definitive conclusions but the comments reveal that some legal practitioners are able to reflect on key elements of their practice in terms of driving their 'legal practice as a business'.

For one RRR ILP, the impact of gaining the status of incorporation was beneficial to its practice management structure as described below: 
Our practice management knowledge is structured and organised. There is a coordinating committee that includes the Directors. Minutes are taken and disseminated; reporting occurs once a month. In terms of strategic management knowledge - there is high sharing of this knowledge. There must be consensus through discussion and opportunities for formal meetings. We meet fortnightly or monthly using video links between [rural location], [rural location] and [urban location]. (Partner, Legal Practitioner Director ILP)

This particular participant's law firm also indicated that they performed highly in terms of business management knowledge, strategic knowledge and formalised methods of practice management.

\section{Opportunities to reward staff}

Similarly, four of the five legal practitioners were consistent in their comments about the ability to pass on the characteristics of incorporation to staff (and other participants).

It has given us flexibility with our legal staff remuneration. We would consider profit sharing. We could implement salary structure based on increases for experience and seniority. We would implement salary sacrificing. (Partner, Legal Practitioner Director ILP)

Research shows that the use of ILPs as a method of succession planning has been considered. Anne Susskind stated that:

New partners can be brought into equity gradually according to their performance or capacity to purchase shares ... Younger solicitors are likely to be heavily burdened by HECS debts and home mortgages and therefore in no position to buy out a full partnership share. They can take up shares gradually ... This gives a firm a greater capacity to retain ... lawyers ... It is an easier way to allow entry and exit of partners. ${ }^{108}$

\section{Considerations of ethics}

The small sample size makes it difficult to draw definitive conclusions about the use and benefits of ILPs. Nevertheless, it is worth noting that participants, in discussing the use of ILPs, focussed on financial protection, improving business management systems and opening up opportunities for attracting and retaining staff, and on succession planning. None of the participants made any reference to or linked ILPs with ethical compliance, which was one of the original rationales for enabling ILPs. ${ }^{109}$ References to potential ethical issues were only raised indirectly in the discussion on the competing roles of running a legal practice and providing legal advice. Discussions on ethics certainly did arise throughout the interviews. In most instances, participants raised the issue of ethical compliance voluntarily. However discussion of ethics was linked to the achievement of ethical compliance as being a major trigger of health and stress related issues rather than a topic in its own right.

In spite of this lack of explicit discussion of ethics, it could be implied that the conflict between the practice of law and the managing of business is an ethical issue. That is, good business management never forgets that the practise of law is within the context of professional and ethical standards; at the very core of a successful law firm are strong, clear ethics. Mayson notes the relationship between law as a competitive business structure and the need for ethical compliance, seeing them as both being important objectives:

By adopting business techniques and outlook, a law firm does not cease to carry on a professional activity ... The most consistent and successful firms ... will be those which remember that the practice of law is both a business and a profession, keeping an eye on the economics and supply of legal services but never losing sight of the ethics and values that underpin a strong and independent profession. ${ }^{110}$

\footnotetext{
108 Susskind, above n 16, 19.

109 Refer generally to Mark (2004), above n 50, Briton (2008), above n 52 and Parker (2010), above n 49.

110 Stephen Mayson, 'The Future of the Legal Profession' (1992) 1 Nottingham Law Journal 1, 4.
} 


\section{Recommendations to reduce inhibitors on the use of ILPs}

The relatively recent legislative responses to provide alternate business structures will assist practitioners deal with the changing nature of legal services in terms of enabling a more competitive business structure to be used for legal practices. The issue for RRR legal practitioners has been their levels of awareness of the new structures and their ability to effectively utilise them.

The literature and the exploratory research indicate that further information and assistance would better prepare current and prospective RRR legal practitioners in using ILPs. Firstly, the Queensland Law Society can assist with the continuing legal education of RRR legal practitioners on the importance of business management practices and the advantages of the appropriate business structures as a means of improving ethical compliance.

RRR legal practitioners need support to put in place 'appropriate management systems'. The exploratory results from this study indicate that more could be done to help practices to understand and implement appropriate management systems. The current take-up of ILPs as the chosen business structure (27 per cent of all law firms) ${ }^{111}$ in Queensland may indicate that levels of confidence to implement a different organisational style are improving. As yet, the breakdown on this figure in terms of RRR legal practitioners is not yet available but these figures may shed further light on the take-up regionally.

Secondly, there is a place for legal education to prepare prospective RRR legal practitioners for the changing environment in which they will provide legal services. The curriculum of legal education needs to take into account not only the demands of RRR legal practice ${ }^{112}$ but also the changing global environment. ${ }^{113}$ In particular, Thomas D. Morgan suggests inclusion of courses that deal with: what it means to think like a lawyer ${ }^{114}$; providing a broad substantive legal knowledge ${ }^{115}$ and learning practical skills. ${ }^{116}$ This list might also include an acknowledgement that 'law is a business' and that part of the curriculum may be broadened to include aspects of 'appropriate management systems' that assist legal practitioners with ethical compliance.

Certainly this approach could be accommodated by (and consistent with) the recent reforms to Australian legal education, framed within the Standards Statement for the Bachelor of Laws as six 'Threshold Learning Outcomes" ${ }^{117}$ that includes the importance of teaching law within the context of its practice.

\footnotetext{
${ }^{111}$ Legal Services Commission, above n 15.

112 Refer to the recent curriculum package: Rethinking Legal Curriculum: Preparing Law Graduates for Practice in Rural and Regional Australia, Rural \& Regional Legal Education Network, Funded by the Australian Government Office for Learning and Teaching, <http://www.rrlen.net.au/> and available to all Australian Law Schools.

${ }^{113}$ For a detailed account of recommendations for reform of legal education to assist with the changing legal environment, refer to Morgan, above n 2, Chapter 5.

${ }^{114}$ Ibid 179.

115 Ibid 181.

116 Ibid 182.

117 Australian Learning and Teaching Council, Learning and Teaching Academic Standards Project: Bachelor of Laws Learning and Teaching Academic Standards Statement (Department of Education, Employment and Workplace Relations, 2010). The TLOs are the result of the task set by the Australian Qualifications Framework Council, Australian Qualifications Framework (1 ${ }^{\text {st }}$ ed, 2011) <http: / / www.aqf.edu.au/ Portals/0/Documents/Handbook/AustQuals\%20FrmwrkFirstEditionJuly2011_FINAL.pdf>, which anticipated that outcomes would be described for each level of qualification.

The six 'Threshold Learning Outcomes' (TLOs) are: TLO 1: knowledge; TLO 2: ethics and professional responsibility; TLO 3: thinking skills; TLO 4: research skills; TLO 5: communication and collaboration; and TLO 6: self-management.
} 